\title{
THE ECHR AND THE PROTECTION OF IRREGULAR MIGRANTS IN THE SOCIAL SPHERE
}

\author{
Sylvie Da Lomba*
}

For more than a decade, the Council of Europe has expressed deep concern over irregular migrants' poor access to basic social rights. With this in mind, I consider the extent to which the European Convention on Human Rights can contribute to protect irregular migrants in the social sphere. To this end, I consider the role of international supervisory bodies in social rights adjudication and discuss the suitability of international adjudication as a means to uphold irregular migrants' social rights. Having reached the conclusion that international adjudication can help protect irregular migrants' social rights, I examine the 'social dimension' of the European Convention on Human Rights and the significance that the European Court of Human Rights attaches to immigration status. I posit that the importance that the Court attaches to resource and immigration policy considerations in $N v$. United Kingdom significantly constrains the ability of the European Convention on Human Rights to afford irregular migrants protection in the social sphere.

keywords, irregular migrants, social rights, European Convention on Human Rights

\section{Introduction}

For more than a decade, the Council of Europe has expressed deep concern over irregular migrants' poor access to human rights in Europe. ${ }^{1}$ Calls for greater protection, however, have remained largely unanswered owing to the unprecedented problematisation of irregular migration. $^{2}$ Irregular migration covers a range of situations which include: clandestine arrival in the host State, staying beyond the permitted period of residence, or working without a permit or in a manner inconsistent with one's immigration status. ${ }^{3}$ The term irregular migrant also applies to foreign nationals who enter on false papers, refused asylum-seekers who have exhausted their appeal rights and can no longer remain in the host State, and regularised

\footnotetext{
* Dr Sylvie Da Lomba is a Lecturer at the Law School of the University of Strathclyde.

${ }^{1}$ See e.g. Council of Europe, Commissioner for Human Rights, The human rights of irregular migrants in Europe (CommDH/IssuePaper (2007), 17 December 2007); and Council of Europe, Parliamentary Assembly, Human rights of irregular migrants (Doc. 10924, 4 May 2006).

${ }^{2}$ See e.g. Council of Europe, Parliamentary Assembly, see supra note 1.

${ }^{3}$ E. Guild, 'Who is an Irregular Migrant?', in B. Bogusz, R. Cholewinski, A. Cygan and E. Szyszczak (eds.), Irregular Migration and Human Rights: Theoretical, European and International Perspectives (Martinus Nijhoff Publishers, Leiden/Boston, 2004) p. 3.
} 
migrants who fall back into an irregular situation. ${ }^{4}$ Irregular migrants' access to basic social rights has been identified as an area of particular concern. ${ }^{5}$ Because irregular migrants have breached immigration laws, the realisation of their social rights is set against the exercise of the Government immigration power. Yet irregular migrants have rights; International Human rights Law (IHRL) confers rights, including social rights, on irregular migrants as persons, irrespective of their immigration status.

With this in mind, I consider the extent to which the European Convention on Human Rights $(\mathrm{ECHR})^{6}$ can help address the protection needs of irregular migrants in the social sphere. There are three reasons for focusing on this human rights instrument. First, while the rights enshrined in the ECHR are in the main civil and political, the Convention can apply to socio-economic conditions. ${ }^{7}$ Secondly, the ECHR is central to the European human rights system. Finally and importantly, irregular migrants present in States Parties to the ECHR fall within the personal scope of the Convention. ${ }^{8}$ This is a critical point as irregular migrants largely fall outside the protection of the law on account of their immigration status. ${ }^{9}$

Whether the ECHR can achieve its potential, however, is contingent on the European Court of Human Rights (ECtHR) asserting the 'social dimension' of the Convention in respect of irregular migrants. ${ }^{10}$ With a view to assessing the Court's approach to protection in the social sphere, I first look at the role of international supervisory bodies in social rights adjudication and then discuss the suitability of international adjudication as a means to protect irregular migrants' social rights. Having come to the conclusion that international adjudication can help protect irregular migrants' social rights, I consider the 'social dimension' of the ECHR as well as the significance that the ECtHR attaches to applicants' immigration status. Finally, I examine the Court's approach in $N v$. United Kingdom as this

\footnotetext{
${ }^{4}$ S. Da Lomba, 'Irregular Migrants and the Human Right to Health Care: a Case-Study of Health-Care Provision for Irregular Migrants in France and the UK', 7:3 International Journal of Law in Context (2011) p. 379.

${ }^{5}$ R. Cholewinski, Study on Obstacles to Effective Access of Irregular Migrants to Minimum Social Rights (Strasbourg, Council of Europe Publishing, 2005).

${ }^{6}$ European Convention on Human Rights (ECHR), ETS No. 5, 4 November 1950 (entry into force: 3 September 1953).

7 See e.g. Airey v. Ireland, 9 October 1979, ECHR, no. 6289/73, para. 26, http://hudoc.echr.coe.int/sites/eng/pages/search.aspx?i=001-57420, visited on 23 October 2014.

${ }^{8}$ Article 1 ECHR provides that "[t] he High Contracting Parties shall secure to everyone within their jurisdiction the rights and freedoms [...] [set out in the ECHR]."

${ }^{9}$ Council of Europe, Commissioner for Human Rights, see supra note 1.

${ }^{10}$ The term 'social dimension' is used by O'Cinneide (C. O'Cinneide, 'A Modest Proposal: Destitution, State Responsibility and the European Convention on Human Rights', 5 European Human Rights Law Review (2008) pp. 583-605.
} 
judgment has far-reaching consequences for the ECHR's ability to protect irregular migrants in the social sphere. ${ }^{11}$

\section{International social rights adjudication: the role of international supervisory bodies}

The judicialisation of social rights remains a controversial issue notwithstanding the development of a significant body of national and international jurisprudence. ${ }^{12}$ My intention here is not to revisit this debate; rather it is to discuss international supervisory bodies' role in social rights adjudication with a view to assessing the ECtHR's approach to protection in the social sphere. With this in mind, I briefly consider the objections to adjudication based on the nature of social rights. I then focus on the objections grounded in international supervisory bodies' (alleged) lack of legitimacy and expertise to deal with matters of State social policy, especially where resource allocation is at issue.

Objections have been levelled against the judicialisation of social rights on account of their (perceived) distinct nature; the argument is that their vague, essentially positive and resource-dependent nature makes them ill-suited for adjudication. These traits, however, are not specific to social rights and may also be ascribed to civil and political rights. The phrasing of social rights does not fundamentally differ from that of civil and political rights. ${ }^{13}$ Both categories of rights may give rise to positive as well as negative obligations. ${ }^{14}$ It follows that both are capable of having resource implications. ${ }^{15}$ While social rights may be more resource-intensive than civil and political rights, the difference is one of "degree rather than substance". ${ }^{16}$ Moreover, objections based on the nature of social rights do not sit well with the integrated approach to interpretation developed by adjudicating bodies, including the

$11 \quad$ v $\quad$ United Kingdom, 27 May 2008, ECHR (GC), no. 26565/05, $<$ http://hudoc.echr.coe.int/sites/eng/pages/search.aspx?i=001-86490>, visited on 23 October 2014.

${ }^{12}$ See e.g. M. Langford (ed.), Social Rights Jurisprudence, Emerging Trends in International and Comparative Law (Cambridge University Press, Cambridge/New York/Melbourne/Madrid/Cape Town/Singapore/São Paolo/Delhi/Tokyo/Mexico City, 2008); and C. Gearty and V. Mantouvalou, Debating Social Rights (Hart Publishing, Oxford/Portland, 2011).

${ }^{13}$ For example, "the right to freedom of speech is no more concrete in expression than the right to social security” (M. Langford, 'The Justiciability of Social Rights: From Practice to Theory', in Langford, see supra note 12 , p. 30$)$.

${ }^{14}$ For example, while the right to a fair trial may place a range of positive obligations on states, the right to housing may require States to exercise restraint. For instance, the right to housing may require States to stay eviction (see e.g. Government of the Republic of South Africa v. Grootboom and Others 2000 (11) BCLR 1169 (CC) ('Grootboom')).

${ }^{15}$ For example, the realisation of the right to a fair trial involves significant public spending.

${ }^{16}$ M. Langford, 'The Justiciability of Social Rights: From Practice to Theory', in Langford, see supra note 12 , p. 30 . 
ECtHR. ${ }^{17}$ This approach rests on the premise that there can be no bright line between social rights and civil and political rights owing to the indivisibility of human rights. ${ }^{18}$

The main objection to the international adjudication of social rights lies with the issue of legitimacy. 'The objection is formally based on the idea of sovereignty but encapsulates the idea that national democracy processes are better suited to matters of social policy. ${ }^{19}$ International bodies are deemed to lack the necessary legitimacy to make decisions on State social policy, especially in respect of resource distribution, with the consequence that the international adjudication of social rights is seen as an encroachment on the State's power. ${ }^{20} \mathrm{I}$ concur with Langford that the legitimacy objection lacks teeth. "States have accepted human rights obligations in international human rights treaties and customary law and submitted to the jurisdiction of [international] bodies." ${ }^{21}$ Significantly, the legitimacy objection rests on the premise that adjudication amounts to giving international supervisory bodies the power to make decisions on matters of State social policy. This view, however, is not based on an accurate account of international bodies' role in the adjudication process. Indeed, international rights adjudication is concerned with human rights protection. Consequently, international supervisory bodies' role is not to make policy choices; rather their role is to ascertain whether States' policy decisions are consistent with their human rights obligations. The approach developed by the European Committee of Social Rights (ECSR) exemplifies this. As part of its adjudicating role, the ECSR assesses whether States' social policy decisions are congruent with their obligations under the European Social Charter (in its original and revised form) ${ }^{22} \cdot{ }^{23}$ The ECSR expects States to meet their obligations "within a reasonable time, with measurable progress and to an extent consistent with the maximum use

\footnotetext{
${ }^{17}$ V. Mantouvalou, 'In Support of Legalisation', see supra note 12, pp. 85-171 and pp. 114-116. This approach was first adopted by the ECtHR in Airey v. Ireland (see supra note 7, para. 26).

${ }^{18}$ See e.g. Preamble to the International Covenant on Economic, Social and Cultural Rights, adopted by General Assembly resolution 2200A (XXI) of 16 December 1966 (entry into force: 3 January 1976).

${ }^{19}$ M. Langford, 'The Justiciability of Social Rights: From Practice to Theory', in Langford, see supra note 12 , p. 34.

${ }^{20}$ The legitimacy objection is also raised in the context of national adjudication. See e.g. M. Wesson, 'Disagreement and the Constitutionalisation of Social Rights', 12:2, Human Rights Law Review (2012) pp. 212253. Sceptics take the view that judicialisation 'hands too much power to the courts and so is undemocratic' (C. Gearty, 'Against Judicial Enforcement', see supra note 12, p. 58). For a critique of this argument, see e.g. M. Langford, 'The Justiciability of Social Rights: From Practice to Theory', in Langford, see supra note 12, p. 32.

${ }^{21}$ Ibid., p. 34.

${ }^{22}$ European Social Charter, CETS No. 35, 18 October 1961 (entry into force: 26 February 1965), Appendix, point 1; and Revised European Social Charter, CETS No. 163, 3 May 1996 (entry into force: 1 July 1999).

${ }^{23}$ See e.g. Autism-Europe v. France, 4 November 2003, European Committee of Social Rights, Complaint No. 13/2002, para. 53; European Roma Rights Centre v. Bulgaria, 18 October 2006, European Committee of Social Rights, Complaint No. 31/2005, para. 37,; and Marangopoulos Foundation for Human Rights (MFHR) $v$. Greece, 6 December 2006, European Committee of Social Rights, Complaint No. 30/2005, para. 204.
} 
of available resources", especially in respect of the most vulnerable individuals. ${ }^{24}$ Thus, while States are required to justify their social policy choices in light of their human rights obligations, their power to make decisions on resource allocation, and more broadly social policy, remains intact. ${ }^{25}$ For example, in Autism-Europe v. France, the ECSR rejected the complainant organization's argument that funding for the education of autistic children and adults should come from the education budget, which would have amounted to ring fencing funding. ${ }^{26}$ Importantly, in addition to advancing social rights protection, international adjudication and the scrutiny of States' policy choices it entails can help promote "a culture of justification", ${ }^{27}$ which fosters Government accountability and legitimacy. Furthermore, the legitimacy objection overlooks the fact that States may enjoy a certain degree of latitude in the implementation of their international human rights obligations. ${ }^{28}$ For instance, States Parties to the ECHR enjoy a particularly broad margin of appreciation when complaints raise issues linked to resource allocation. ${ }^{29}$

Understanding international supervisory bodies' role in social rights adjudication as a means to assess the compliance of States' policy decisions with their human rights obligations also addresses the expertise objection. The latter is generally levelled against social rights adjudication in national contexts, but it is also raised in respect of international

\footnotetext{
${ }^{24}$ Autism-Europe v. France, see supra note 23, para. 53. The ECSR had previously applied a common standard for all States in respect of progressive rights, irrespective of their relative economic wealth (see U. Khaliq and R. Churchill, 'The European Committee of Social Rights, Putting Flesh on the Bare Bones of the European Social Charter', in Langford, see supra note 12, p. 434).

${ }^{25}$ The approach of the ECSR is resonant with the model of review developed by the South African Constitutional Court (see e.g. S. Liebenberg, 'Adjudicating Social Rights under a Transformative Constitution', in Langford, see supra note 12, pp. 75-101; and A. Pillay, 'Courts, Variable Standards of Review and Resource Allocation: Developing a Model for the Enforcement of Social and Economic Rights', 6 European Human Rights Law Review (2007) pp. 616-626). For example, in Grootboom, the Court held that it would not prescribe particular choices to the Government, but would scrutinise Government policy in light of its constitutional obligations (see supra note 14, para. 41). However, national courts have at times adopted a more prescriptive approach. See e.g. Colombian Constitutional Court, SU-225/98. In this decision, the Court ordered the authorities to put in place a free infant vaccination programme for the poor. The Court's approach was based on the idea that, while the right to health was generally progressive in nature, "it may crystallise into an immediate entitlement where there [was] a nexus with a fundamental right such as life, integrity or dignity' (M. Wesson, see supra note 20, pp. 242-243).

${ }^{26}$ Autism-Europe v. France, see supra note 23, para. 54. The ECSR found that "France ha[d]failed to achieve sufficient progress in advancing the provision of education for persons with autism' ( $\mathrm{ibid}$.). France was found in violation of Articles 15(1) and Article 17(1) 'whether alone or read in combination with Article E of the Revised European Social Charter" (ibid.).

${ }^{27}$ This expression was coined by Etienne Mureinik (E. Mureinik, 'A Bridge to Where? Introducing the Interim Bill of Rights', 10 South African Journal of Human Rights (1994) pp. 31-32).

${ }^{28}$ M. Langford, 'The Justiciability of Social Rights: From Practice to Theory', in Langford, see supra note 12, p. 34 .

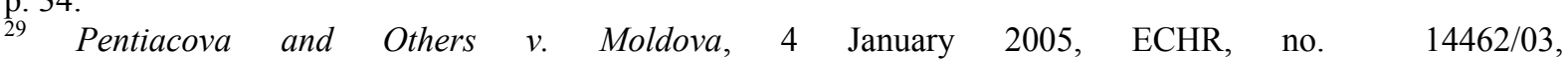
$<$ http://hudoc.echr.coe.int/sites/eng/pages/search.aspx?i=001-67997>, visited on 23 October 2014. In contrast with the ECtHR, the ECSR has been more reluctant to allow States a margin of appreciation. The ECSR first granted a margin of appreciation to States in Quaker Council for European Affairs v. Greece (Quaker Council for European Affairs v. Greece, 25 April 2001, European Committee of Social Rights, Complaint No. 8/2000).
} 
adjudication. ${ }^{30}$ As is the case with the legitimacy objection, the expertise objection rests on the assumption that social rights adjudication grants adjudicating bodies the power to make decisions on social policy. According to this objection, adjudicating bodies lack the necessary expertise to deal with the complex matters that arise in social rights complaints. ${ }^{31}$ However, Langford convincingly points out that if judges" role "is not to decide policy and resource allocation but rather to assess whether the State [...] ha[s] adequately complied with [its] legal obligations, then they need not be "policy wonks". What is required is essentially the exercise of 'traditional' judicial competences". ${ }^{32}$ Besides, "when courts lack technical knowledge, judges can be trained and can hear experts' opinions". ${ }^{33}$ Moreover, the expertise objection is particularly hard to sustain in respect of bodies especially set up to adjudicate social rights. $^{34}$

Critics of social rights adjudication further point out that adjudicating bodies lack the legitimacy and expertise to tackle issues which have repercussions beyond individual cases and contend that such issues are best left to the State's executive and legislative power. ${ }^{35}$ However, I posit that polycentric concerns are overstated in the debate on social rights adjudication. First, while social rights claims often raise complex issues, these are not necessarily polycentric in nature. ${ }^{36}$ Secondly, polycentricity is not confined to social rights claims and courts have handled polycentric concerns in other contexts as King's analysis of the English courts' case law on taxation shows. ${ }^{37}$ Finally, the polycentric argument overlooks the fact that the role of adjudicating bodies is not to make decisions on matters of State policy, polycentric or otherwise, but to examine States' policy choices in light of their human rights obligations. It follows that the assumptions that polycentricity is inherent in social rights claims and that international adjudication is ill-equipped to deal with polycentric issues are ill-founded. ${ }^{38}$

\section{Is international social rights adjudication for irregular migrants?}

\footnotetext{
${ }^{30}$ Pentiacova and Others $v$. Moldova, see supra note 29.

${ }^{31}$ See e.g. M. Wesson, 'Equality and Social Rights: an Exploration in Light of the South African Constitution', Winter, Public Law (2007) p. 761.

${ }^{32}$ M. Langford, 'The Justiciability of Social Rights: From Practice to Theory', in Langford, see supra note 12 , p. 35 .

${ }^{33}$ V. Mantouvalou, 'In Support of Legalisation', see supra note 12, p. 118.

${ }^{34}$ For example, the ECSR has adjudicated rights the realisation of which is "exceptionally complex" (AutismEurope v. France, see supra note 23, para. 53).

${ }^{35}$ See L. Fuller, 'The Forms and Limits of Adjudication', 92 Harvard Law Review (1978-1979) pp. 353-409, discussed in J. King, 'The Pervasiveness of Polycentricity', Spring, Public Law (2008) pp. 101-124.

${ }^{36}$ Ibid., p. 103.

${ }^{37}$ Ibid.

${ }^{38}$ Langford makes this point in respect of social rights adjudication in national courts (M. Langford, 'The Justiciability of Social Rights: From Practice to Theory', in Langford, see supra note 12, p. 36).
} 
Irregular migrants experience severe difficulties in accessing human rights. ${ }^{39}$ This begs the question whether human rights are the problem; or whether the problem lies with the implementation and enforcement of human rights. This, in turn, raises questions as to the role of international adjudication in the protection of irregular migrants' social rights. ${ }^{40}$

The principal criticism levelled against IHRL relates to its failure to deliver on its universal promise. IHRL predicates rights on personhood; yet the realisation of human rights remains largely contingent on membership in the national community. This creates a tension between the universal premise of IHRL and the exercise of the Government immigration power. This tension is particularly acute in the social sphere because States construe social rights as membership rights, notwithstanding their recognition in IHRL. ${ }^{41}$ This characterisation of social rights as membership rights is rooted in States' understanding of the welfare State as a social cooperation scheme that binds members together. As a result, the social rights that underpin the welfare State are only bestowed on members in the national community. ${ }^{42}$ Predicating social rights on membership has significant consequences for migrants. While national citizenship is no longer a prerequisite for membership in the socioeconomic domain, ${ }^{43}$ migrants' eligibility for membership remains conditional on their immigration status. Accordingly, and in contrast with permanent regular migrants, ${ }^{44}$ irregular migrants are refused membership in the national community on account of their having breached immigration laws. ${ }^{45}$ Irregular migrants' lack of membership renders them ineligible for social (membership) rights, which causes their exclusion from welfare distribution. Two factors compound States' objections to social rights for irregular migrants. First, the crisis of the welfare State means that the distribution of limited resources to non-members is

\footnotetext{
${ }^{39}$ See supra note 1.

${ }^{40}$ Similar questions are raised by Dembour and Kelly in M-B. Dembour and T. Kelly, 'Introduction', in M-B. Dembour and T. Kelly (eds.), Are Human Rights for Irregular Migrants? Critical Reflections on the Status of Irregular Migrants in Europe and the United States (Routledge, Oxon, 2011) p. 6.

${ }^{41}$ See e.g. S. Da Lomba, see supra note 4, pp. 380-382.

${ }^{42}$ Ibid., p. 381.

${ }^{43}$ The divide between citizens and non-citizens, however, remains resilient in the political sphere. This may be explained by States' self-understanding as bounded nation-States (R. Brubaker, Citizenship and Nationhood in France and Germany (Harvard University Press, Cambridge MA, 1992), p. 28). See also Y. N. Soysal, Limits of Citizenship, Migrants and Postnational Membership in Europe (Chicago University Press, Chicago, 1994).

${ }^{44}$ Hammar coined the term denizen to describe the legal status of regular migrants who are long-term residents and as such have acquired full membership in the socio-economic domain (T. Hammar, Democracy and the Nation State (Avebury, Aldershot, 1990) pp. 12-13).

${ }^{45}$ See e.g. S. Da Lomba, see supra note 4, pp. 380-382. States regard irregular migrants as a threat to both the State's power to control its borders and the national community's right to self-determination (D. Dauvergne, 'Sovereignty, Migration and the Rule of Law in Global Times', 67:4 Modern Law Review (2004) p. 601).
} 
increasingly set against national priorities. ${ }^{46}$ Secondly, States take the view that welfare provision for irregular migrants encourages irregular migration. ${ }^{47}$

I posit that sceptics of human rights overstate the flaws in the universal premise of IHRL. The latter has never claimed that it could make legal status in the nation-State irrelevant. IHRL forms part of International Law and as such is, inter alia, shaped by the principle of national sovereignty. ${ }^{48}$ Consequently, the Government immigration power has a bearing on the normative content of IHRL. This, in turn, explains why IHRL does not compel States to confer the full set of human rights on migrants. For example, the International Convention on the Protection of the Rights of All Migrant Workers and Members of their Families bestows basic social rights on irregular migrants, but only grants enhanced rights to regular migrants. ${ }^{49}$ However, as this example shows, the State-centred nature of IHRL does not obviate protection. While IHRL cannot fully bridge the rights-gaps arising from legal status in the nation-State, it can carve out a zone of protected personhood for migrants, including irregular migrants, by attaching rights to the person.

The concept of human dignity has played an important part in upholding personhood as a source of rights for irregular migrants in the context of human rights adjudication. For example, in a challenge to the validity of a statute limiting irregular migrants' rights (social as well as civil and political), the Spanish Constitutional Court "characterised [irregular] migrants not as outlaws [...], but as persons endowed with human dignity". 50 Another example may be found in the ECSR's approach to the adjudication of irregular migrants' social rights. The European Social Charter (in its original and revised form) provides that rights are conferred on "foreigners only in so far as they are nationals of other Parties lawfully resident or working regularly within the territory of the Party concerned." International Federation of Human Rights Leagues (FIDH) v. France (FIDH v. France), however, the ECSR interpreted the personal scope of the Charter so as to offer some

\footnotetext{
${ }^{46}$ S. Da Lomba, see supra note 4, p. 391.

${ }^{47} \mathrm{Ibid}$., p. 392. For example, States have curtailed health care provision for irregular migrants which constrains the realisation of their human right to health care (ibid.).

${ }^{48}$ S. Meckled-García and B. Çali, 'Human Rights Legalized - Defining, Interpreting and Implementing an Ideal', in S. Meckled-García and B. Çali (eds.), The Legalization of Human Rights: Multidisciplinary Perspectives on Human Rights and Human Rights Law (Routledge, London/New York, 2005) pp. 17-18.

${ }^{49}$ International Convention on the Protection of the Rights of All Migrant Workers and Members of their Families, adopted by General Assembly resolution 45/158 of 18 December 1990 (entry into force: 1 July 2003), respectively Parts III and IV.

${ }^{50}$ STC 237/2007, FJ3, referred to in M. Rodrígues and R. Rubio-Marín, 'Testing the Boundaries of Human Rights Protection in Spain and the United States', see supra note 40, p. 87. The Constitutional Court, however, only invalidated the statutory provisions which denied irregular migrants education and free legal assistance (ibid., p. 89).

${ }^{51}$ Appendix, point 1, European Social Charter (original and revised form).
} 
protection to irregular migrants. ${ }^{52}$ The complainant organization argued that reforms to health care provision for irregular migrants in France breached Articles 13 (right to social and medical assistance) and 17 (right of children and young persons to social, legal and economic protection) of the Revised European Social Charter. ${ }^{53}$ The French Government submitted that irregular migrants fell outside the personal scope of the Charter. ${ }^{54}$ The ECSR, however, opined that the condition relating to lawful residence only applied to equal treatment with nationals. ${ }^{55}$ The Committee asserted that "the Charter must be interpreted so as to give life and meaning to fundamental social rights" and that restrictions on rights must therefore "be read restrictively". ${ }^{56}$ It emphasised that "[h] uman dignity [was] the fundamental value and indeed the core of positive European human rights law - whether under the European Social Charter or under the European Convention on Human Rights" 57 and stressed that "health care [was] a prerequisite for the preservation of human dignity." 58 On this basis, the ECSR found that France had breached Article 17 by depriving irregular migrants' children of immediate access to health care, save in cases of emergency. ${ }^{59}$ The Committee, however, held that France had not violated Article 13 as adult irregular migrants were not denied all entitlement to medical assistance. ${ }^{60}$ The decision in FIDH $v$. France was not unanimous; dissenting ECSR members, whilst they deplored irregular migrants' predicament, opined that their inclusion in the personal scope of the Charter went against the letter of its Appendix. ${ }^{61}$ The Parliamentary Assembly of the Council of Europe observed that "[ $t]$ he reasoning underlying the Committee's decision [did] not completely neutralise the exclusion of foreign nationals provisions of the Appendix. ${ }^{.62}$ It noted that these provisions were only overrode "in one particular circumstance, namely when their application could have consequences that are

52 International Federation of Human Rights Leagues (FIDH) v. France, 8 September 2004, European Committee of Social Rights, Complaint No. 14/2003.

${ }^{53}$ Ibid., paras. 16-17, 20, 22-23 and 25.

${ }^{54}$ Ibid., paras. 18-19.

${ }^{55}$ Ibid., paras. 26-32.

${ }^{56}$ Ibid., para. 29.

${ }^{57}$ Ibid., para. 31.

${ }^{58}$ Ibid.

${ }^{59}$ Ibid., paras. 35-37. Barriers on children and adolescents' access to health care were subsequently lifted by the French Government (Circulaire DHOS/DSS/DGAS, No. 2005-141 of 16 March 2005 relative à la prise en charge des soins urgents délivrés à des étrangers résidant en France de manière irrégulière et non bénéficiaires de l'aide médicale de l'Etat, Bulletin officiel du ministère chargé des affaires sociales n 2005/4, 170-72).

${ }^{60}$ International Federation of Human Rights Leagues (FIDH) v. France, see supra note 52, paras. 33-34. Two ECSR members opined that France had also violated Article 13 (ibid., Dissenting Opinion of Mr Tekin Akillioğlu and Dissenting Opinion of M. Jean-Michel Belorgey).

${ }^{61}$ Ibid., Dissenting Opinion of Mr Stein Evju joined by Mrs Polonca Koncar and Mr Lucien François and Dissenting Opinion of Mr Rolf Birk.

${ }^{62}$ Council of Europe, Parliamentary Assembly, Committee on Migration, Refugees and Population, The European Social Charter and Protection of Illegal Immigrants (AS/Mig/Inf (2005) 17, 28 September 2005) p. $9)$. 
incompatible with human dignity". ${ }^{63}$ The Assembly's comment, however, does not quite reflect the ECSR's reasoning in that the ECSR presented the inclusion of irregular migrants as a matter of interpretation, not as a deviation from the Charter's Appendix provisions. ${ }^{64}$ In line with its approach in FIDH v. France, ${ }^{65}$ the Committee found that The Netherlands' denial of access to adequate housing to children unlawfully present in its territory engaged Articles 31(2) and 17 of the Revised European Social Charter. ${ }^{66}$ Significantly, the ECSR's explicit affirmation of the Government immigration power, something the Committee had not done in FIDH v. France, ${ }^{67}$ did not cause the Committee to reconsider irregular migrants' inclusion in the scope of the Charter. It follows from the ECSR's approach that the notion of human dignity is central to reconciling the exercise of the Government immigration power with States' human rights obligations, and ultimately to asserting personhood as a source of social rights for irregular migrants. Importantly, these cases show that the ECSR is willing to link the concept of human dignity to social rights, even when their realisation requires the redistribution of limited national resources. ${ }^{68}$

The case law of the ECSR shows that international adjudication can play a part in the protection of irregular migrants' social rights. However, it remains the case that these migrants are often reluctant "to pursue legal protections and remedies [...], even when their most basic rights are at stake", for fear of coming to the attention of the authorities. ${ }^{69}$ Carens rightly points out that immigration enforcement will continue to hinder human rights protection unless a "firewall", based on the principle that "no information gathered by those responsible for protecting and realizing basic human rights can be used for immigration enforcement purposes", is erected. ${ }^{70}$ Because irregular migrants' immigration status constrains the realisation and protection of their social human rights, some contend that

\footnotetext{
${ }^{63} \mathrm{Ibid}$. (emphasis added).

${ }^{64}$ International Federation of Human Rights Leagues (FIDH) v. France, see supra note 52, paras. 26-29.

${ }^{65}$ Ibid.

${ }^{66}$ Defence for Children International (DCI) v. The Netherlands, 20 October 2009, European Committee of Social Rights, Complaint No. 47/2008. Article 31(2) of the Revised Social Charter provides that "[w]ith a view to ensuring the effective exercise of the right to housing, the Parties undertake to take measures designed [...] to prevent and reduce homelessness with a view to its gradual elimination". The respondent Government informed the Committee of Ministers that, whilst it did not support the ECSR's reasoning in respect of the inclusion of irregular migrants, it was committed to ensuring "the effective implementation of the rights of children unlawfully present in its jurisdiction" (Committee of Ministers, Resolution CM/ResChS(2010)6, Appendix and point 1).

${ }^{67}$ Defence for Children International (DCI) v. The Netherlands, see supra note 66, para. 41.

${ }^{68}$ This approach is not confined to cases involving irregular migrants. See e.g. Autism-Europe v. France, see supra note 23. See also H. Cullen, 'The Collective Complaints System of the European Social Charter: Interpretative Methods of the European Committee of Social Rights', 9:1 Human Rights Law Review (2009) p. 78.

${ }^{69}$ J. H. Carens, 'The Rights of Irregular Migrants', 22:2 Ethics \& International Affairs (2008) p. 167.

${ }^{70}$ Ibid., pp. 167-168.
} 
solutions to irregular migrants' predicament lie with political rather than legal processes. ${ }^{71}$ Political processes, however, come with their own drawbacks. For example, a political party that wishes to accede to power or to be re-elected is unlikely to support welfare provision for irregular migrants, especially in times of economic crisis. ${ }^{72}$ Mantouvalou observes that politicians are more 'likely to succumb to populist pressures' than judges. ${ }^{73}$ Moreover, irregular migrants often lack the political leverage to initiate and shape political solutions. ${ }^{74}$ In my view, the barriers to access to human rights protection faced by irregular migrants, however, do not negate the value of international adjudication. Besides, it is important to note that international adjudication does not always depend on individuals bringing a complaint. For example, the collective complaints system of the European Social Charter allows organizations representing employers and employees as well as some NGOs to make complaints. ${ }^{75}$ It follows that political processes should complement rather than supplant legal processes.

\section{The ECtHR and protection in the social sphere}

The ECHR "guarantees, for the most part, civil and political rights." ${ }^{76}$ However, in Airey v. Ireland, the ECtHR asserted that there could be "no water-tight division" between civil and political rights and social and economic rights. ${ }^{77}$ On this basis, the Court held "that the mere fact that an interpretation of the Convention may extend into the sphere of social and economic rights should not be a decisive factor against such an interpretation". ${ }^{78}$ Accordingly, the ECtHR developed an integrated approach to the interpretation of the ECHR with the consequence that the Convention may apply to socio-economic conditions. ${ }^{79}$ With this in mind, I consider the ECtHR's approach to protection in the social sphere. The primary aim is to determine whether the Court offers a forum for scrutinising States' social policy

\footnotetext{
${ }^{71}$ See e.g. M. Rodrígues and R. Rubio-Marín, 'Testing the Boundaries of Human Rights Protection in Spain and the United States', in Dembour and Kelly, see supra note 40.

${ }^{72}$ For example, Governments have sought to curtail welfare provision for irregular migrants rather than improve their treatment in the social sphere. S. Da Lomba, see supra note 4.

${ }^{73}$ V. Mantouvalou, 'In Support of Legalisation', see supra note 12, p. 125.

${ }^{74}$ M-B. Dembour and T. Kelly, 'Introduction, in Dembour and Kelly, see supra note 40, p. 11. See also M. Rosello, 'Representing Illegal Immigrants in France: from Clandestins to l'Affaire des Sans-Papiers de SaintBernard', 28:1 Journal of European Studies (1998) pp. 137-151.

${ }^{75}$ Additional Protocol to the European Social Charter Providing for a System of Collective Complaints, CETS No. 158, 9 November 1995 (entry into force: 1 July 1998), Article 1.

${ }^{76}$ R. C. A. White and C. Ovey, The European Convention on Human Rights (Oxford University Press, Oxford, 2010) p. 8. However, there are exceptions; for example, Articles 1 and 2 of the First Protocol to the ECHR respectively protect property rights and the right to education.

${ }^{77}$ Airey v. Ireland, see supra note 7, para. 26.

${ }^{78}$ Ibid.

79 See e.g. M.S.S. v. Belgium and Greece, 21 January 2011, ECHR (GC), no. 30696/09, http://hudoc.echr.coe.int/sites/eng/pages/search.aspx?i=001-103050, visited on 23 October 2014.
} 
choices in light of their ECHR obligations. The focus is on health care complaints as these raise salient questions of resource distribution.

In line with its integrated approach, the ECtHR has held that the ECHR could give rise to obligations in the field of health care. For example, the Court has repeatedly asserted that States' failure to provide prisoners with adequate medical assistance breached Article 3 when the ensuing harm attained the requisite severity threshold. ${ }^{80}$ Health care standards in Contracting States may also beget complaints under Article $2 .{ }^{81}$ For example, in $L C B v$. United Kingdom, the ECtHR held that Article 2(1) "enjoins the State not only to refrain from the intentional and unlawful taking of life, but also to take appropriate steps to safeguard the lives of those within its jurisdiction". ${ }^{82}$ In Cyprus v. Turkey, the Court found that Article 2 could be engaged "where it is shown that the authorities [...] put an individual's life at risk through the denial of health care which they have undertaken to make available to the population generally." ${ }^{, 83}$ It follows that the Court "might find a violation of the Convention where there has been a failure to provide basic medical care, leading to death or serious injury". ${ }^{84}$ The ECtHR has also accepted "the theoretical possibility of the Convention [...] [generating] wider obligations". ${ }^{85}$ For example, the Court has asserted that Article 8 could give rise to obligations in the field of health care. ${ }^{86}$ However, the ECtHR remains "extremely

\footnotetext{
${ }^{80}$ For example, in Keenan $v$. United Kingdom, the Court found that the lack of adequate medical treatment for a prisoner suffering from schizophrenia amounted to degrading treatment (Keenan v. United Kingdom, 3 April 2001, ECHR, no. 27229/95, para. 116, <http://hudoc.echr.coe.int/sites/eng/pages/search.aspx?i=001-59365>, visited on 23 October 2014). Likewise, in Khudobin v. Russia, the Court found that a prisoner who was HIV positive and suffered from several chronic diseases had not received the medical assistance he needed in violation of Article 3 (Khudobin v. Russia, 26 October 2006, ECHR, no. 59696/00, $<$ http://hudoc.echr.coe.int/sites/eng/pages/search.aspx?i=001-77692>, visited on 23 October 2014). Whether the minimum severity threshold is attained 'depends on the circumstances of the case, such as the duration of the treatment, its physical or mental effects and, in some cases, the sex, age and state of health of the victim' (see e.g. Ireland $v$ United Kingdom, 18 January 1978, CHR, no. 5310/71, para. 162, $<$ http://hudoc.echr.coe.int/sites/eng/pages/search.aspx?i=001-57506>, visited on 23 October 2014).

${ }_{81}$ See e.g. Nitecki v. Poland, 21 March 2002, ECHR, no. 65653/01, http://hudoc.echr.coe.int/sites/eng/pages/search.aspx?i=001-22339, visited on 23 October 2014; and Pentiacova and Others $v$. Moldova, see supra note 29.

${ }_{82} \quad L C B \quad v$. United Kingdom, 9 June 1998, ECHR, no. 23413/94, para. 36, http://hudoc.echr.coe.int/sites/eng/pages/search.aspx?i=001-58176, visited on 23 October 2014. See also Kontrová v. Slovakia, 31 May 2007, ECHR, no. 7510/04, para. 49, $<$ http://hudoc.echr.coe.int/sites/eng/pages/search.aspx?i=001-80696>, visited on 23 October 2014.

${ }_{83}$ Cyprus v .Turkey, 10 May 2001, ECHR, no. 25781/94, para. 219, http://hudoc.echr.coe.int/sites/eng/pages/search.aspx?i=001-59454, visited on 23 October 2014.

${ }^{84}$ L. Clements and A. Simmons, 'European Court of Human Rights, Sympathetic Unease', in Langford, see supra note 12, p. 418.

${ }^{85}$ Ibid.

${ }^{86}$ See e.g. Pentiacova and Others v. Moldova, see supra note 29. In this case, the ECtHR found the Article 8 complaint to be manifestly ill-founded (ibid.).
} 
hesitant about reading into the Convention a positive obligation to provide health care", beyond what may be regarded as extreme circumstances. ${ }^{87}$

The ECtHR's timid approach to protection in the social sphere is attributable to two factors. The first factor pertains to the range of rights enshrined in the ECHR. The Court's integrated approach to interpretation has not turned the ECHR into a socio-economic rights instrument. The ECtHR has repeatedly held that "the Convention d[id] not guarantee, as such, socio-economic rights, including the right to charge-free dwelling, the right to work, the right to free medical assistance, or the right to claim financial assistance from a State to maintain a certain level of living." 88 The second factor relates to the ECtHR's approach to questions touching on the distribution of national resources. The ECtHR has always been cautious not to "impose an impossible or disproportionate burden" on States. ${ }^{89}$ Consequently, concerns over resource implications for States have prompted the Court to limit the range of positive obligations that the ECHR may beget in the field of health care. Accordingly, the Court has asserted that Article 2 did not place an obligation on States "to provide an effective system of healthcare" 90 and that Article 8 did not encompass a right to particular forms of medical treatment. $^{91}$ In Article 8 cases, the Court has sought to strike a fair balance between the competing interests of the individual and the general interest. ${ }^{92}$ For instance, in Pentiacova and others v. Moldova (Pentiacova v. Moldova), the ECtHR accepted that "Article 8 was applicable to [...] complaints about insufficient funding of treatment." 93 However, while the

\footnotetext{
${ }^{87}$ L. Clements and A. Simmons, 'European Court of Human Rights, Sympathetic Unease', in Langford, see supra note 12, p. 418.

${ }_{88}$ ECtHR, Pancenko v. Latvia, 28 October 1999, ECHR, no. 40772/98, $<$ http://hudoc.echr.coe.int/sites/eng/pages/search.aspx?i=001-4912>, visited on 23 October 2014. See also e.g. O' Rourke v. United Kingdom, 26 June 2001, ECHR, no. 39022/97, $<$ http://hudoc.echr.coe.int/sites/eng/pages/search.aspx?i=001-5933>, visited on 23 October 2014; and Marzari $v$. Italy, 4 May 1999, ECHR, no. 36448/97,< http:/hudoc.echr.coe.int/sites/eng/pages/search.aspx?i=001-22827>, visited on 23 October 2014. In Botta v. Italy, the Court found that '[ $\mathrm{t}$ ]he rights asserted by the applicant were social in character' and as such 'went beyond the concept of legal obligation' under Article 8(1) (Botta v. Italy, 24 February1998, ECHR, no. 21439/93, para. 28, <http://hudoc.echr.coe.int/sites/eng/pages/search.aspx?i=001$58140>$, visited on 23 October 2014).

${ }^{89}$ Kontrová v. Slovakia, see supra note 82, para. 50, citing Osman v. United Kingdom, 28 October 1998, ECHR, no. 23452/94, para. 116, <http://hudoc.echr.coe.int/sites/eng/pages/search.aspx?i=001-58257>, visited on 23 October 2014.

${ }^{90}$ C. O'Cinneide, see supra note 10, p. 590.

91 Pentiacova and Others v. Moldova, see supra note 29. This is also implicit in Nitecki v. Poland (see supra note 81). For example, in Sentges v. The Netherlands, the Court found the applicant's complaint that the authorities' refusal to provide him with a robotic arm violated Article 8 manifestly ill-founded (Sentges $v$. The Netherlands, 8 July 2003, ECHR, no. 27677/02, <http://hudoc.echr.coe.int/sites/eng/pages/search.aspx?i=00123318>, visited on 23 October 2014).

${ }^{92}$ Botta v. Italy, see supra note 88 , para. 33. The balance must be fair in that States remain under the obligation 'to secure the practical and effective protection of rights.' See e.g. Kontrová v. Slovakia, see supra note 82, para. 51.

${ }^{93}$ Pentiacova and Others v. Moldova, see supra note 29.
} 
Court did not question the applicants' assertion that they could not afford necessary treatment and medication that was not provided free of charge by the State, it held "that the applicants' claim amount[ed] to a call on public funds which, in view of the scarce resources, would have to be diverted from other worthy needs funded by the taxpayer." 94 The Court pointed out that, "[w]hile it [was] clearly desirable that everyone should have access to a full range of medical treatment $[\ldots]$, the lack of resources mean[t] that there [we]re, unfortunately, in the Contracting States many individuals who d[id] not enjoy them, especially in cases of permanent and expensive treatment." 95

The margin of appreciation doctrine is central to the ECtHR's approach to questions raising issues of resource allocation. The Court has constantly held that States' margin of appreciation is wider in the socio-economic sphere. ${ }^{96}$ In Pentiacova v. Moldova, the Court emphasised that the margin of appreciation enjoyed by States in the socio-economic sphere was "even wider when (...) the issues involve[d] an assessment of the priorities in the context of the allocation of limited resources", in this instance health care resources. ${ }^{97}$ Significantly, the Court asserted that national authorities were better placed than an international court to undertake this kind of assessment because they were familiar with the demands made on national health care systems and the resources available to meet those demands. ${ }^{98}$ This is in line with the Court's approach in Connors v. United Kingdom. ${ }^{99}$ In this case, the Court stated that "in spheres such as housing, which play[ed] a central role in the welfare and economic policies of modern societies, it w[ould] respect the legislature's judgment as to what [wa]s in the general interest unless that judgment [wa]s manifestly without reasonable foundation". 100 It follows that the Court will, in principle, leave questions involving matters of resource

\footnotetext{
94 Ibid.

95 Ibid. The Court also observed 'that the applicants had access to the standard of health care offered to the general public' and that health care reform had improved their situation (ibid.).

96 Connors v. United Kingdom, 27 May 2004), ECHR, no. 66746/01, para. 82, $<$ http://hudoc.echr.coe.int/sites/eng/pages/search.aspx?i=001-61795>,visited on 23 October 2014. See also e.g. Budayeva and Others v. Russia, 20 March 2008, ECHR, nos. 15339/02, 21166/02, 20058/02, 11673/02 and 15343/02, para. 135, <http://hudoc.echr.coe.int/sites/eng/pages/search.aspx?i=001-85436>, visited on 23 October 2014. In James and Others v. United Kingdom, the Court emphasised that "the margin of appreciation available to the legislature in implementing social and economic policies should be a wide one" (James and Others v. United Kingdom, 21 February 1986, ECHR, no. 8793/79, para. 46, $<$ http://hudoc.echr.coe.int/sites/eng/pages/search.aspx?i=001-57507>, visited on 23 October 2014). States' margin of appreciation is also wide in the technical sphere (Budayeva and Others v. Russia, see supra note 96, para. 135).

${ }_{97}^{97}$ Pentiacova and Others v. Moldova, see supra note 29, (emphasis added).

${ }^{98}$ Ibid.

${ }^{99}$ Connors v. United Kingdom, see supra note 96.

${ }^{100}$ Ibid.
} 
distribution, and more broadly social policy, to States. ${ }^{101}$ This in turn means that the Court will not, as a matter of course, scrutinise States' policy choices in light of their ECHR obligations. This, in my view, significantly constrains the 'social dimension' of the ECHR.

\section{The ECtHR and irregular migrants}

Irregular migrants present in the territory of Contracting States fall within the ECHR personal scope and as such are bestowed the rights enshrined in the Convention. ${ }^{102}$ Whether their rights may be effectively protected in the ECtHR, however, is contingent on the Court reconciling the exercise of the Government immigration power with States' ECHR obligations. $^{103}$

In immigration cases, the ECtHR has constantly maintained States' right to regulate immigration as its starting point ${ }^{104}$ and stressed that the ECHR does not guarantee the right to enter and reside in a State which is not the State of nationality. ${ }^{105}$ The Court, however, subjects the exercise of the Government immigration power to States' ECHR obligations. ${ }^{106}$ Accordingly the ECtHR has upheld the conventional rights of irregular migrants who find themselves within the jurisdiction of Contracting States. For example, in Siliadin v. France, the Court held that the respondent State's failure to afford effective protection against forced labour to a minor who was unlawfully present in its territory violated Article 4. ${ }^{107}$ Significantly the Court has accepted that Article 8 could, in certain circumstances, place an obligation to regularise illegal stay. ${ }^{108}$ Moreover, the Court has also been willing to reassess

\footnotetext{
101 The Court's readiness to defer is not 'an uniquely socio-economic phenomenon' (L. Clements and A. Simmons, 'European Court of Human Rights, Sympathetic Unease', in Langford, see supra note 12, p. 409). See e.g. Osman v. United Kingdom, see supra note 89, para. 116. ${ }^{102}$ Article 1 ECHR.

${ }^{103}$ I have already stressed that effective protection is also conditional on irregular migrants having access to legal protections and remedies.

104 See e.g. Chahal v. United Kingdom, 15 November 1996, ECHR, no. 22414/93, para. 73, $<$ http://hudoc.echr.coe.int/sites/eng/pages/search.aspx?i=001-58004>, visited on 23 October 2014; Boultif v. Switzerland, 2 August 2001, ECHR, no. 54273/00, para. 46, $<$ http://hudoc.echr.coe.int/sites/eng/pages/search.aspx?i=001-59621>, visited on 23 October 2014; and Aswat $v$. United Kingdom, 16 April 2013, ECHR, no. 17299/12, para. 49, $<$ http://hudoc.echr.coe.int/sites/eng/pages/search.aspx?i=001-118583>, visited on 23 October 2014.

105 Sisojeva and Others v. Latvia, 16 June 2005, ECHR, no. 60654, para. 99, $<$ http://hudoc.echr.coe.int/sites/eng/pages/search.aspx?i=001-69391>, visited on 23 October 2014. See also AlNashif v. Bulgaria, 20 June 2002, ECHR, no. 50963/99, para. 114, $<$ http://hudoc.echr.coe.int/sites/eng/pages/search.aspx?i=001-60522>, visited on 23 October 2014.

${ }^{106}$ See Chahal v. United Kingdom, see supra note 104, para. 73; Boultif v. Switzerland, see supra note 104, para. 46; and Aswat v. United Kingdom, see supra note 104, para. 49.

107 Siliadin v. France, 26 July 2005, ECHR, no. 73316/01, $<$ http://hudoc.echr.coe.int/sites/eng/pages/search.aspx?i=001-69891>, visited on 23 October 2014. The applicant had worked for a couple, without respite, against her will, and without being paid.

${ }^{108}$ See D. Thym, 'Respect for Private and Family Life under Article 8 ECHR in Immigration Cases: a Human Right to Regularize Illegal Stay?', 57:1 International \& Comparative Law Quarterly (2008) pp. 87-112.
} 
the significance that it attaches to the Government immigration power in cases involving children.

In Slivenko v. Latvia, the Court considered, inter alia, whether the applicants' removal from Latvia pursuant to the 1994 Treaty on the Withdrawal of Russian Troops (1994 Treaty) breached Article 8. ${ }^{109}$ The Court found that the applicants' removal violated their right to respect for private life as it could not be regarded as necessary in a democratic society. ${ }^{110}$ In Sisojeva and Others v. Latvia, the Court found that the Latvian authorities' prolonged refusal to recognize the applicants' right to permanent residence in application of the 1994 Treaty violated Article 8 as the State's interference with their right to respect for private life could not be justified under Article 8(2). ${ }^{111}$ The case, however, was referred to the Grand Chamber at the request of Latvia. The Grand Chamber agreed that the applicants had endured a period of insecurity and legal uncertainty, but opined that they did not face "any real and imminent risk of deportation" and observed that they had failed to make any attempt to regularise their status in spite of the authorities' recommendations. ${ }^{112}$ On this basis, the Grand Chamber held that the options offered by the authorities to the applicants to regularise their immigration status had been "adequate and sufficient" to remedy their Article 8 complaint. ${ }^{113}$ While the Grand Chamber concurred that the ECHR could impose an obligation to regularise unlawful stay in particular circumstances, it sought to avoid a "substantive overstretch of Article 8 which the earlier chamber judgment $[\ldots]$ might have entailed". 114

The question whether Article 8 could give rise to an obligation to regularise illegal stay also arose in expulsion cases concerning parental rights. In Rodrigues Da Silva and Hoogkamer v. The Netherlands (Rodrigues Da Silva), the ECtHR assessed whether the deportation of an irregular migrant breached this person as well as her daughter's Article 8 rights. ${ }^{115}$ The Court emphasised that

Article 8 [did] not entail a general obligation for a State to respect immigrants' choice of the country of their residence and to authorise family reunion in its territory.

\footnotetext{
$109 \quad$ Slivenko v. Latvia, 9 October 2003, ECHR (GC), no. 48321/99, $<$ http://hudoc.echr.coe.int/sites/eng/pages/search.aspx?i=001-61334>, visited on 23 October 2014.

${ }^{110}$ Ibid., paras. 113-129.

${ }^{111}$ Sisojeva. and Others $v$ Latvia, see supra note 105, paras. 99-111.

112 Sisojeva v. Latvia, 15 January 2007, ECHR (GC), no. 60654/00, paras. 100-101, $<$ http://hudoc.echr.coe.int/sites/eng/pages/search.aspx?i=001-79022>, visited on 23 October 2014.

${ }^{113}$ Ibid., para. 102.

${ }^{114}$ D. Thym, see supra note 108, p. 98.

115 Rodrigues Da Silva and Hoogkamer v. The Netherlands, 31 January 2006, ECHR, no. 50435/99, $<$ http://hudoc.echr.coe.int/sites/eng/pages/search.aspx?i=001-72205>, visited on 23 October 2014. The mother shared the care of her daughter with her former partner, a Dutch national. See also Hamidovic v. Italy, 13 September 2011, ECHR, no. 31956/05, <http://hudoc.echr.coe.int/sites/eng/pages/search.aspx?i=001-106519>, visited on 23 October 2014.
} 
Nevertheless, in a case which concern[ed] family life as well as immigration, the extent of a State's obligations to admit to its territory relatives of persons residing there $\mathrm{w}$ [ould] vary according to the particular circumstances of the persons involved and the general interest. [ $\left.{ }^{116}\right]$

In this instance, the Court stated that it was in the child's best interests to allow her mother to stay. ${ }^{117}$ Importantly the Court stressed that "the economic well-being of the State [did] not outweigh the applicants' rights under Article 8", regardless of the mother's unlawful residence. ${ }^{118}$ The ECtHR's reasoning in Rodrigues Da Silva ${ }^{119}$ is similar to the Court's approach in Mubilanzila Mayeka and Kaniki Mitunga v. Belgium (Mubilanzila v. Belgium) ${ }^{120}$ in that the Court downplayed the importance that it normally accorded to the Government immigration power. The applicants, a mother and daughter, claimed that the child's detention and subsequent deportation to the DRC violated, inter alia, their Articles 3 and 8 rights. ${ }^{121}$ The ECtHR found Belgium in breach of both provisions. ${ }^{122}$ The ECtHR emphasised that the absolute nature of Article 3 was the "decisive factor" and that "it [took] precedence over considerations relating to the applicant's status as an illegal immigrant." ${ }^{123}$ In Polidario $v$. Switzerland, the ECtHR departed from its well-established approach in immigration cases in that it did not refer to the State's right to regulate immigration. The Court unanimously held that the Swiss authorities' refusal to issue the applicant with a residence permit over a period of six years breached her right to respect for her family life. ${ }^{124}$ The Court emphasised that the respondent State's failure to assist the applicant with the enforcement of her parental rights largely accounted for her illegal presence in Switzerland. ${ }^{125}$ The applicant was a national of the Philippines. She had lived in Geneva and had a child with a Swiss national. She had returned to the Philippines with her son because her leave to remain had not been renewed. The applicant held custody rights and parental authority in respect of the child. The father had been allowed to have his son for the holidays, but had not returned him to the Philippines. All the applicant's attempts to obtain her child's return to the Philippines were unsuccessful. Her

\footnotetext{
${ }^{116}$ Rodrigues Da Silva and Hoogkamer v. The Netherlands, see supra note 115, para. 39.

117 Ibid., para. 44.

118 Ibid.

119 Ibid.

${ }^{120}$ Mubilanzila Mayeka and Kaniki Mitunga v. Belgium, 12 October 2006, ECHR, no. 13178/03, $<$ http://hudoc.echr.coe.int/sites/eng/pages/search.aspx?i=001-77447>, visited on 23 October 2014.

${ }^{121}$ Ibid., paras. 64 and 88 .

${ }^{122}$ Ibid., paras. 66-71 and 75-91. The Court also found that Article 5(1) and (4) had been breached in respect of the daughter (ibid., paras. 95-105 and 109-114).

${ }^{123}$ Ibid., para. 55.

${ }^{124}$ Polidario v. Switzerland, 30 July 2013, ECHR, no. 33169/10, para. 78,

$<$ http://hudoc.echr.coe.int/sites/eng/pages/search.aspx?i=001-122977>, visited on 23 October 2014.

${ }^{125}$ Ibid., paras. 73-77.
} 
requests for leave to remain in Switzerland were all rejected. Custody of the child was subsequently awarded to the father. The applicant was granted access rights which had to be exercised in Switzerland; yet she had no authorisation to stay there. She was only granted a one week visa to attend custody proceedings in Switzerland. The applicant decided to remain in Switzerland illegally in order to exercise her access rights.

These cases show that the ECtHR can reconcile the exercise of the Government immigration power with States' ECHR obligations and consequently protect irregular migrants' ECHR rights. These cases, however, do not signify a shift in the ECtHR's approach in immigration cases in that the State's right to regulate immigration remains the starting point in the Court's reasoning, save where children's basic human rights and their best interests are at stake.

\section{6. $N$ v. United Kingdom: when immigration status trumps effective protection}

It is well-established in the ECtHR's case law that the ECHR has a 'social dimension' and that, whilst the Court upholds States' right to control immigration, irregular immigration status does not, in principle, constitute a bar to protection. It follows that the ECHR is capable of offering protection, albeit limited, to irregular migrants in the social sphere. In this section, however, I posit that the Court's approach in cases on the expulsion of the seriously ill undermines the level of protection that the Convention may afford irregular migrants.

The Court first considered whether the expulsion of a seriously ill person engaged the ECHR in $D v$. United Kingdom. ${ }^{126}$ The applicant claimed that his expulsion to his home country upon completion of his prison sentence would violate Article $3 .^{127}$ The ECtHR first observed that $D v$. United Kingdom should be distinguished from other Article 3 cases in that the respondent State could not be held responsible, directly or indirectly, for the risk of illtreatment. ${ }^{128}$ In this instance, the risk of harm arose from the lack of adequate health care provision in the receiving State. The ECtHR, however, unanimously held that, given the importance of Article 3 to the ECHR system, "sufficient flexibility" was required in the application of this provision and that " $[\mathrm{t}$ ]o limit the application of Article $3[\ldots]$ in this manner would be to undermine the absolute character of its protection." "129 Having

$126 \quad D \quad v$. $\quad$ United Kingdom, 2 May 1997, ECHR, no. 30240/96, $<$ http://hudoc.echr.coe.int/sites/eng/pages/search.aspx?i=001-58035>, visited on 23 October 2014. In an earlier case, the European Commission on Human Rights had opined that the removal of a national of Ghana who suffered from an eye condition did not engage Article 3 (Tanko v. Finland, 19 May 1994, European Commission on Human Rights, no. 23634/94).

${ }^{127}$ D v. United Kingdom, see supra note 126, paras. 40-41.

${ }^{128}$ Ibid., para. 49.

${ }^{129}$ Ibid. 
established that Article 3 could apply to wider contexts, the Court found that "the conditions of adversity which await[ed] [the applicant] in St Kitts [would] further reduce his already limited life expectancy and subject him to acute mental and physical suffering." ${ }^{\text {130 }}$ The Court placed much emphasis on the fact that $D$ was terminally ill. In light of the applicant's "very exceptional circumstances", the Court held that his expulsion would violate Article $3 .{ }^{131}$

In subsequent cases, however, the ECtHR found that the expulsion of seriously ill persons would not engage the ECHR. ${ }^{132}$ The judgment of the Grand Chamber in N. United Kingdom is of particular relevance in this respect. ${ }^{133}$ In this case, the ECtHR considered whether an HIV patient's removal to Uganda would violate Article 3. The Court agreed with the applicant that her removal would cause her condition to deteriorate and would significantly shorten her life expectancy. ${ }^{134}$ The Court, however, observed that she was not "critically ill" 135 and that she was "fit to travel". ${ }^{136}$ The applicant's health status was decisive in the ECtHR's assessment that her case did "not disclose very exceptional circumstances". 137

On this basis, the Court distinguished her circumstances from $D$ 's and concluded that $N$ 's removal to Uganda would not violate Article $3 .{ }^{138}$

Significantly, the ECtHR asserted that "[a]dvances in medical science, together with social and economic differences between countries, entail[ed] that the level of treatment available in the Contracting State and the country of origin may vary considerably". ${ }^{139}$ On this basis, the Court held that to find the respondent State in breach of Article 3 would amount to requiring States "to alleviate such disparities through the provision of free and

\footnotetext{
${ }^{130}$ Ibid., para. 52.

${ }^{131}$ Ibid., para. 53.

${ }_{132}$ See e.g. S.C.C. v. Sweden, 15 February 2000, ECHR, no. 46553/99, $<$ http://hudoc.echr.coe.int/sites/eng/pages/search.aspx?i=001-5079>, visited on 23 October 2014; Bensaid v. United Kingdom, 6 February 2001, ECHR, no. 44599/98, $<$ http://hudoc.echr.coe.int/sites/eng/pages/search.aspx?i=001-59206, > visited on 23 October 2014; Arcila Henao v. The Netherlands, 24 June 2003, ECHR, no. 13669/03, $<$ http://hudoc.echr.coe.int/sites/eng/pages/search.aspx?i=001-23281>, visited on 23 October 2014; Ndangoya $v$. Sweden, 22 June 2004, ECHR, no. 17868/03, http://hudoc.echr.coe.int/sites/eng/pages/search.aspx?i=00124018, visited on 23 October 2014; and Amegnigan v. The Netherlands, 25 November 2004, ECHR, no. 25629/04, <http:/hudoc.echr.coe.int/sites/eng/pages/search.aspx?i=001-67675>, visited on 23 October 2014. In B.B. v. France, the European Commission on Human Rights found that the deportation of an AIDS patient to the DRC would violate Article 3. The case was referred to the ECtHR, but was struck out of the list following the French Government's undertaking not to deport the applicant (B.B. v France, 7 September 1998, ECHR, no. 30930/96, <http://hudoc.echr.coe.int/sites/eng/pages/search.aspx?i=001-58224>, visited on 23 October 2014).

${ }^{133} N$ v. United Kingdom, see supra note 11.

${ }^{134}$ Ibid., para. 50.

${ }^{135}$ Ibid.

${ }^{136}$ Ibid.

${ }^{137}$ Ibid., para. 51.

${ }^{138}$ Ibid.

${ }^{139}$ Ibid., para. 44.
} 
unlimited health care to all aliens without a right to stay within its jurisdiction." 140 This, in the Court's opinion, would place "too great a burden on Contracting States". ${ }^{141}$ I posit that concerns over imposing overly burdensome obligations on the respondent State were at the heart of the ECtHR's reasoning and non-violation finding in $N v$. United Kingdom. ${ }^{142}$ I do not dispute that resource and immigration policy considerations can have a bearing on the adjudication of ECHR rights. The ECtHR has constantly maintained States' right to control immigration. ${ }^{143}$ It is also well-established in the case law of the Court that States enjoy a wider margin of appreciation in the socio-economic sphere ${ }^{144}$ and that this margin is particularly broad in respect of resource allocation issues. ${ }^{145}$ Importantly, the Court has always been careful not to place 'an impossible or disproportionate burden' on States. ${ }^{146}$ What I take issue with, however, is the significance that the ECtHR accords to resource and immigration policy considerations in $N$ v. United Kingdom. ${ }^{147} \mathrm{I}$ contend that these considerations are the starting point in the Court's reasoning and that they prompt the Court to depart from principles central to the ECHR.

In the dissenting judges' opinion, the majority were concerned that finding the UK in breach of Article 3 "would open up the floodgates to medical immigration and make Europe vulnerable to becoming the "sick-bay" of the world". ${ }^{148}$ The 'floodgate argument' rests on the assumption that welfare provision acts as a pull factor for irregular migration. It is commonly used by Governments to justify curtailments of welfare provision for irregular migrants, in spite of the lack of supportive evidence. ${ }^{149}$ Paradoxically, the ECtHR did not engage with the

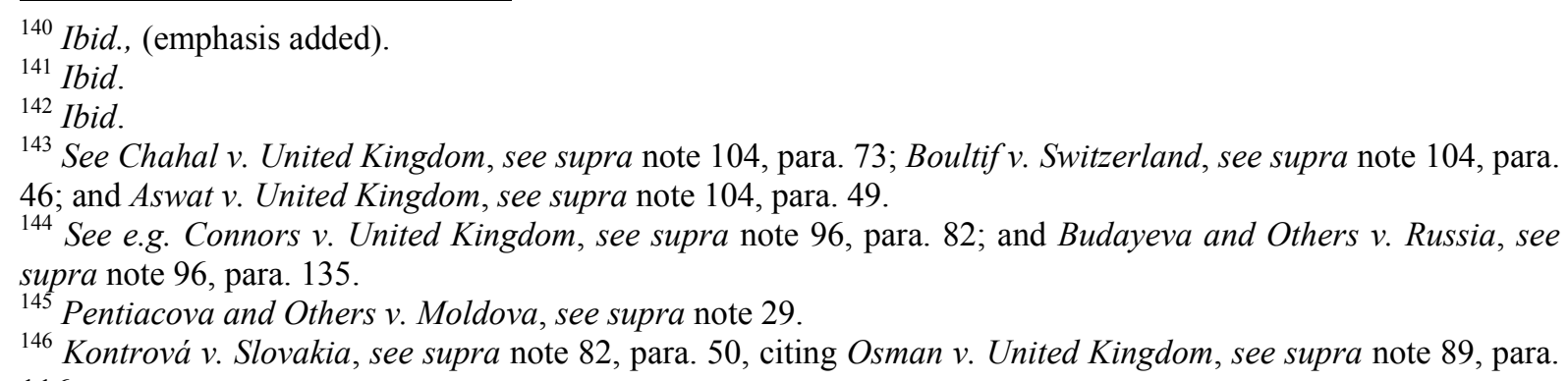
116.

${ }^{147} N$ v. United Kingdom, see supra note 11.

${ }^{148}$ Ibid., Joint Dissenting Opinion of Judges Tulkens, Bonello and Spielmann, para. 8.

${ }^{149}$ For example, in 2010, the UK Government recommended that overseas visitors' entitlements to free NHS health care be curtailed with a view to, inter alia, curbing health tourism. Yet, in the same policy document, the UK Government admitted that only "[a] small proportion of visitors engaged in health tourism" (Department of Health (England), Review of Access to the NHS by Foreign Nationals, Consultation Proposals, February 2010, p. 17 ,

<www.dh.gov.uk/prod_consum_dh/groups/dh_digitalassets/@dh/@en/documents/digitalasset/dh_113243.pdf>, visited on 23 October 2014 ). Overseas visitors are people who are not ordinarily resident in the UK (National Health Service (Charges to Overseas Visitors) Regulations 1989, SI 1989, No. 306, reg. 1(2)). See also V. Bettinson and A. Jones, 'The Integration or Exclusion of Welfare Rights in the European Convention on Human Rights: the Removal of Foreign Nationals with HIV after $N v U K$ (Application No. 26565/05; Decision of the 
very argument that underpinned its approach. Instead it unreservedly espoused the respondent State's view that health care provision for "aliens without a right to stay"150 placed a considerable strain on national health care resources and encouraged irregular migration. ${ }^{151}$ Significantly, the dissenting judges pointed out that "when one compares the total number of requests received (and those refused and accepted) as against the number of HIV cases, the so-called "floodgate" argument is totally misconceived." ${ }^{152}$ Moreover, "it [is] not unusual for applicants to have been unaware of their HIV status when they arrived [in the respondent State]; this was the case in $N v U K$ itself." ${ }^{, 153}$ Besides, irregular migrants are often ignorant of any rights they may have ${ }^{154}$ and their immigration status severely constrains their access to legal protections. ${ }^{155}$ The Court's lack of engagement with the 'floodgate argument' is congruent with its readiness to leave matters of resource allocation to the States' judgment. Indeed the Court is of the view that States are best placed to carry out this kind of assessment. ${ }^{156}$ Yet as an adjudicating body, it falls on the Court to examine whether States' social policy choices are consistent with their ECHR obligations. I argue that $N v$. United Kingdom exposes the risks that the ECtHR's lack of scrutiny poses to effective protection in the social sphere. In this case, the Court did not assess whether the Government's policy on leave to remain on medical grounds met the UK's conventional obligations. Rather the Court unqualifiedly endorsed the argument that underpinned the respondent State's policy, namely the 'floodgate argument', and, on this basis, departed from principles critical to effective protection.

I posit that the ECtHR's approach in $N$ v. United Kingdom ${ }^{157}$ undermines Article 3 protection, the Court's integrated approach to interpretation and the principle according to which States' right to regulate immigration is subject to their ECHR obligations. I contend that the ECtHR's reasoning erodes the fundamental and absolute character of Article 3 on two accounts. First, it introduces a higher severity threshold. In this respect, the dissenting judges opined that, although the applicant was not terminally ill, "[t]here [was] no doubt that in the event of removal to Uganda the applicant [would] face an early death after a period of

Grand Chamber of the European Court of Human Rights, 27 May 2008)', 31:1 Journal of Social Welfare and Family Law (2009) p. 87.

${ }^{150} N$ v. United Kingdom, see supra note 11, para. 44.

${ }^{151}$ Ibid., para. 24.

${ }^{152}$ Ibid., Joint Dissenting Opinion of Judges Tulkens, Bonello and Spielmann, para. 8.

${ }_{153}$ V. Bettinson and A. Jones, see supra note 149, p. 87.

${ }^{154}$ Council of Europe, Commissioner for Human Rights, see supra note 1, Part IV.

${ }^{155}$ See J. H. Carens, see supra note 69, p. 167.

${ }^{156}$ See e.g. Pentiacova and Others v. Moldova, see supra note 29; and Connors v. United Kingdom, see supra note 96.

${ }^{157} N$ v. United Kingdom, see supra note 11. 
acute physical and mental suffering". ${ }^{158}$ Accordingly, they found that the applicant's deportation would violate Article $3 .{ }^{159}$ They stressed that there was no basis for increasing the severity threshold "where the harm stem[med] from a naturally occurring illness and a lack of adequate resources in the receiving country". ${ }^{160}$ In Yoh-Ekale Mwanje v. Belgium, six out of seven judges expressed the view that "this extreme severity threshold - to be close to dying" could not be easily reconciled with the letter and spirit of Article 3, which guarantees an absolute right inherent in human integrity and dignity, and called on the Court to reconsider its approach. ${ }^{161}$ Regrettably, the Court adopted the same approach as in $N v$. United Kingdom, notwithstanding these judges' misgivings. ${ }^{162}$ Secondly, the ECtHR balanced the applicant's right not to be subjected to ill-treatment against resource and immigration policy considerations. Yet it is well-established in the Court's case law, including expulsion cases, that Article 3 rights cannot be balanced against societal interests, no matter how legitimate these may be. ${ }^{163}$ The ECtHR (unconvincingly) attempted to find support for its balancing exercise in its case law. Citing its judgment in Soering v. United Kingdom, the Court emphasised that "[i]nherent in the whole of the Convention is a search for a fair balance between the demands of the general interest of the community and the requirements of the protection of the individual's fundamental rights." 164 The Court, however, omitted to mention that, in Soering v. United Kingdom, it had also asserted that "the object and purpose of the Convention as an instrument for the protection of individual human beings require that its provisions be interpreted and applied so as to make its safeguards practical and effective." ${ }^{, 165}$

The ECtHR's reasoning in $N$ v. United Kingdom also retreats from the Court's integrated approach to interpretation in that the Court concurs with the respondent State that the ECHR is "essentially directed at the protection of civil and political rights". ${ }^{166}$ Ironically,

\footnotetext{
${ }^{158}$ Ibid., Joint Dissenting Opinion of Judges Tulkens, Bonello and Spielmann, para. 23.

${ }^{159}$ Ibid., para. 24.

${ }^{160}$ Ibid., para. 5.

161 Yoh-Ekale Mwanje v. Belgium, 20 December 2011, ECHR, no. 10486/10, Partly Concurring Opinion of Judges Tulkens, Jočienè, Popović, Karakaş, Raimondi and Pinto De Albuquerque, para. 6, $<$ http://hudoc.echr.coe.int/sites/eng/pages/search.aspx?i=001-108155>, visited on 23 October 2014.

${ }_{162}$ These judges explained that their decision to follow the Grand Chamber's approach in $N v$ United Kingdom (see supra note 11) sought to preserve "legal certainty" (ibid.).

${ }^{163}$ See e.g. Chahal v. the United Kingdom, see supra note 104, para. 79; Othman (Abu Qatada) v. United Kingdom, 17 January 2012, ECHR, no. 8139/09, para. 185 , $<$ http://hudoc.echr.coe.int/sites/eng/pages/search.aspx? $\mathrm{i}=001-108629>$, visited on 23 October 2014; and ECtHR, Aswat v. United Kingdom, see supra note 104, para. 49.

${ }^{164} N$ v. United Kingdom, see supra note 11, para. 44, citing Soering v. United Kingdom, 7 July 1989, ECHR, no. 14038/88, para. 89, <http://hudoc.echr.coe.int/sites/eng/pages/search.aspx?i=001-57619>, visited on 23 October 2014.

${ }^{165}$ Ibid., para. 87.

${ }^{166} \mathrm{~N}$ v. United Kingdom, see supra note 11, paras. 44 and 24.
} 
the Court relies on its judgment in Airey v. Ireland, the very judgment that established its integrated approach, to justify its reasoning. ${ }^{167}$ While it is true that the Court has always been cautious not to impose unduly burdensome obligations on States in the social sphere, ${ }^{168}$ it had constantly maintained its integrated approach. Moreover, the Court has been willing to broaden the 'social dimension' of the Convention. For example, in M.S.S. v. Greece and Belgium, the Grand Chamber held that Article 3 was capable of having extraterritorial effect when applied to socio-economic circumstances. ${ }^{169}$

I further contend that the ECtHR's erosion of Article 3 protection and retreat from its integrated approach to interpretation evince the Court's failure to reconcile the exercise of the Government immigration power with States' ECHR obligations. Contrary to it wellestablished case law, ${ }^{170}$ the Court's approach in $N v$ United Kingdom subjects States' ECHR obligations to their right to regulate immigration. Immigration status and its implications for protection in the social sphere were already a consideration in $D v$. United Kingdom. Indeed, in this judgment, the ECtHR emphasised that "aliens who ha[d] served their prison sentences and [we]re subject to expulsion [could not] in principle claim any entitlement to remain in the territory of a Contracting State in order to continue to benefit from medical, social or other forms of assistance provided by the expelling State during their stay in prison." ${ }^{171}$ However, and in contrast with the Court's judgment in $N v$. United Kingdom, ${ }^{172}$ concerns over overstretching Article 3 obligations did not cause the Court to lower protection standards. Thus, in $D$ v. United Kingdom, ${ }^{173}$ immigration status did not become a bar to effective protection. What further distinguishes these two judgments is that the ECtHR's approach in $N$ v. United Kingdom ${ }^{174}$ has the potential to apply to a much larger population and in wider contexts. In $D v$. United Kingdom, the Court expressed the view that the 'social dimension' of the ECHR should be limited in respect of a well-circumscribed group of foreign nationals, namely individuals subject to expulsion measures upon completion of their prison

\footnotetext{
${ }^{167}$ Ibid., para. 44, citing ECtHR, Airey v. Ireland, see supra note 7, para. 26. The dissenting judges, however, pointed out that the majority's citation was incomplete $(N v$. United Kingdom, see supra note 11, Joint Dissenting Opinion of Judges Tulkens, Bonello and Spielmann, para. 6).

${ }^{168}$ See e.g. Pentiacova $v$ Moldova, see supra note 29.

${ }^{169}$ The Grand Chamber found that the conditions of detention and subsistence of an asylum-seeker expelled from Belgium to Greece under the Dublin Regulation breached Article 3 (M.S.S. v. Belgium and Greece, see supra note 79, paras. 214-234). See G. Clayton, 'Asylum Seekers in Europe: M.S.S. v Belgium and Greece', 11:4 Human Rights Law Review (2011) pp. 758-773.

${ }^{170}$ See e.g. Chahal v. the United Kingdom, see supra note 104, para. 79; Othman (Abu Qatada) v. United Kingdom, see supra note 161, para. 185; and Aswat v. United Kingdom, see supra note 104, para. 49.

${ }^{171} D$ v. United Kingdom, see supra note 126, para.54.

${ }^{172} \mathrm{~N} v$. United Kingdom, see supra note 11.

${ }^{173}$ D v. United Kingdom, see supra note 126.

${ }^{174} \mathrm{~N}$ v. United Kingdom, see supra note 11.
} 
sentence. ${ }^{175}$ In $N v$. United Kingdom, the applicant was an asylum-seeker who, having had her claim rejected, was to be removed to her home country. ${ }^{176}$ Yet the Court used the term "aliens without a right to stay". ${ }^{177}$ Critically this term is very broad in scope. In addition to applying to refused asylum-seekers and other persons subject to expulsion measures, it may also encompass irregular migrants who live clandestinely in Contracting States ${ }^{178}$ as well as to those whose removal cannot be effected. ${ }^{179}$ Thus the term 'aliens without a right to stay' may apply to most irregular migrants. ${ }^{180}$ This in turn makes the ECtHR's approach applicable beyond expulsion cases, with the consequence that protection standards could be lowered in cases where the respondent State is actually responsible for the risk of harm.

It follows from the above that the ECtHR's approach in $N v$. United Kingdom ${ }^{181}$ has the potential to obviate effective protection in the social sphere for the vast majority of irregular migrants present in Contracting Parties. In my view, the problem primarily lies with the importance that the Court accords to resource and immigration policy considerations in this case. However, the flaws in the ECtHR's reasoning are also attributable to the Court's reluctance to measure States' policy choices against their ECHR obligations in social complaints.

\section{Conclusion}

I do not contend that the ECHR can "serve as a proxy or stand-in for an enforceable set of socio-economic rights" 182 for irregular migrants. What I posit is that the Convention can help protect this group of migrants in the social sphere. Whether the ECHR can achieve its potential in this respect, however, is contingent on the ECtHR revisiting aspects of its case law. In my opinion, three issues warrant reconsideration on the part of the Court. First, the Court must reassess its readiness to defer questions involving matters of resource allocation to States and overcome its reluctance to scrutinise their policy choices in the social sphere in

\footnotetext{
${ }^{175}$ D v. United Kingdom, see supra note 126, para.54.

${ }^{176} N$ v. United Kingdom, see supra note 11.

${ }^{177}$ Ibid., para. 44.

${ }^{178}$ Many irregular migrants remain undetected by public authorities and, for this reason, are not subject to expulsion measures.

${ }^{179}$ This, for instance, will be the case where the nationality of the individual concerned cannot be ascertained or where the necessary identity documentation cannot be obtained.

${ }^{180}$ One category of irregular migrants who might fall outside the scope of this term are migrants who have the right to remain, but are working without a permit or in manner inconsistent with their permit. Moreover, it follows from the ECtHR's case law that the approach developed in N v United Kingdom is unlikely to apply to children (see supra note 11). Indeed, in cases involving children, the Court has prioritised effective protection over immigration status considerations (see Mubilanzila Mayeka and Kaniki Mitunga v. Belgium, see supra note 120, para. 55; and Rodrigues Da Silva and Hoogkamer v. The Netherlands, see supra note 115, para. 44).

${ }^{181} N$ v. United Kingdom, see supra note 11.

182 This view is also expressed by O'Cinneide (see supra note 10, p. 586).
} 
light of their ECHR obligations. Such a change, however, is conditional on the Court developing a broader understanding of its adjudicating role in social complaints. Secondly, the ECtHR must reassert the fundamental and absolute nature of Article 3 protection as well as its integrated approach to interpretation. Ultimately, whether the ECHR can contribute to protect irregular migrants in the social sphere is conditional on the ECtHR ensuring that States' right to regulate immigration is exercised in a manner consistent with their conventional obligations; something the Court failed to do in $N v$. United Kingdom. ${ }^{183}$ I argue that, until the Court re-evaluates the significance that it accords to irregular immigration status in social complaints, irregular migrants' position vis-à-vis the nation-State will continue to inhibit effective protection.

In the introduction, I have drawn attention to the Council of Europe's repeated calls for greater protection for irregular migrants' basic social rights. The ECtHR's approach in $N$ v. United Kingdom, ${ }^{184}$ however, casts doubt on the Court's willingness to answer these calls. Indeed, rather than bringing irregular migrants under the protection of the ECHR, the Court's approach entrenches their position as 'outlaws' on account of their immigration status. In FIDH v. France, the ECSR emphasised that human dignity was a "fundamental value" at the core of the ECtHR and the Committee's case law. ${ }^{185}$ Accordingly, the ECSR has established a strong link between respect for human dignity and the protection of basic social rights. This in turn has prevented immigration enforcement from undercutting irregular migrants' personhood and enabled the Committee to uphold irregular migrants' basic social rights. ${ }^{186}$ Conversely, the ECtHR's lack of scrutiny of States' policy choices in social complaints combined with the importance that the Court attaches to resource and immigration policy considerations in cases on the expulsion of the seriously ill have so far thwarted the development of a comparable link in the Court's case law. In my view, the ECtHR's approach not only frustrates the ECHR's ability to protect irregular migrants in the social sphere, it also constrains the 'social dimension' of the Convention to the detriment of all within the jurisdiction of Contracting Parties.

\footnotetext{
${ }^{183} N$ v. United Kingdom, see supra note 11.

${ }^{184}$ Ibid.

${ }^{185}$ International Federation of Human Rights Leagues (FIDH) v. France, see supra note 52, para. 31.

${ }^{186}$ Ibid. See also Defence for Children International (DCI) v. The Netherlands, see supra note 66.
} 